\title{
The Heartlands of Neoliberalism and the Rise of the Austerity State Bob Jessop
}

Pre-copy-edited version of Chapter 35 in S. Springer, K. Birch, and J. MacLeavy, eds., Handbook of Neoliberalism (London: Routledge, 2016), ISBN 9781138844001.

My chapter explores the genealogy and development of neoliberalism in its heartlands. What happens here is closely entangled with events, processes and forces elsewhere in the world market, the world of states and global society. I first consider the meaning of heartlands and note some paradoxes in its use in geopolitics, geoeconomics and critical studies of neoliberalism. Second I present a typology of neoliberalism, note its hybrid forms, and offer a periodization for its instantiation in the 'heartlands', where its dominant form is principled neoliberal regime shifts. The best-known cases are the United States and United Kingdom. I then note that pragmatic neoliberal policy adjustments can cumulate, through ratchet-like effects, to produce de facto regime shifts. Here I briefly consider Germany, the leading example given its central position in the European Union. I conclude with brief comments on the implications of such regime shifts in the heartlands for (1) core-periphery relations in the heartlands themselves, associated with its intensification of uneven development and (2) the overall dynamic of a world market organized in the shadow of neoliberalism.

\section{Where are the Heartlands?}

This term has five meanings that are relevant here. First, for the British geopolitical theorist, Halford MacKinder (1904), it denotes the Eurasian Heartland, which comprises nearly $60 \%$ of the world land area. MacKinder claimed that 'Who rules East Europe commands the Heartland; who rules the Heartland commands the WorldIsland; who rules the World-Island commands the world' (1919: 106, italics removed). Beyond the heartland, he argued, lies a less important hemisphere (comprising the Americas and Australia) plus outlying smaller islands (including, for example, Japan and the UK) and the oceans. To limit Eurasian power, it was necessary to fragment the central landmass and control its rimlands, especially, its western and eastern poles. The US achieved this after 1945 thanks to the Iron Curtain (and, later, the SinoSoviet split), through its hegemony in Western Europe and Japan, and its dominance 
in Eurasia's soft Middle Eastern underbelly. Thus seen, apart from an abortive neoliberal system transformation after the collapse of the Soviet Union, which had occupied a significant part of the Eurasian heartland, it is a paradox that the outer crescent now forms the heartlands of neoliberalism and has been using neoliberalism to destabilize the rimlands in Eastern and Central Europe.

Second, a radical international relations scholar, Kees van der Pijl, distinguishes a liberal, Lockean heartland from a series of 'contender state. The former is characterized by disembedded markets and strong civil societies that underpin the inter-state system; the latter are dominated by a strong political apparatus with centralized control of resources mobilized to challenge the leading economic powers and their inter-state system (van der Pijl 1998). Thus viewed, the Lockean heartland has been transformed into the neoliberal heartland and, under US hegemony, is seeking to integrate or undermine new contenders through hard, soft, and smart power - including a series of global neoliberal initiatives together with efforts to achieve full spectrum dominance militarily. This can be seen in the pivot to the East to contain a semi-neoliberal China and the launch of the Third Cold War against Russia based on neoliberalism and NATO.

Third, for theorists like Jamie Peck and Adam Tickell (2002) or Philip Mirowski and Dieter Plehwe (2009), the neoliberal heartland is understood in terms of a coreperiphery relation. Whereas the first two accounts imply a latent or open antagonism between heartland and periphery, Peck and Tickell explore the diffusion of neoliberalism from its intellectual or political heartlands into successive zones of extension. However, as it travels to particular cities, regions, or nation-states in Latin America, Africa, Asia, and Eastern Europe, it mutates in response to local conditions (Peck and Tickell 2002). So, rather than assuming a self-identical Neoliberalism, they highlight processes of variegated neoliberalization as neoliberal ideas and policies undergo hybridization.

Fourth, Wendy Larner (2003) has criticized this core-periphery diffusion thesis on the grounds that the neoliberal project was relatively marginal in the Lockean heartlands until its feasibility was demonstrated in Chile and elsewhere in Latin America. It then migrated back to the 'ideological heartlands' as an apparently successful policy 
paradigm. Larner, a New Zealander, also notes that ex-politicians and technocrats from her homeland were key advisors to Eastern European governments on their privatization strategies. Indeed, she argues that "developments in the "periphery" may be as significant, if not more so, as those in the "core" in explaining the spread of neoliberalism' (Larner 2003: 510).

Fifth, and finally, the term is sometimes merely a geographical and historical descriptor that regards the heartlands of neoliberalism as comprising, at a minimum, the United States and United Kingdom, with optional references to Canada, Australia, and New Zealand. Together these countries comprise the Anglo-Saxon heartlands of neoliberalism. Some add Western Europe, although, as noted below, this conflates societies that engaged in neoliberal policy adjustments with the neoliberal regime shifts that occurred in the real heartlands. Even here, however, Kean Birch has recently argued that the heartlands 'have never been neoliberal'. More precisely, and less provocatively, he means that the pure theory of neoliberalism was never really implemented in the United States, Canada and the United Kingdom (his three case studies) but served as a rhetorical cloak for policies that promoted, not free markets, but the freedom of monopolistic corporations to limit competition, derive superprofits, and colonize the wider society (Birch 2015: 18 and passim). He adds that many of the symptoms of financial, economic, debt, and austerity crises attributed to neoliberalism preceded the alleged ascendancy of neoliberalism; nor is there anything new about financial crises, which have occurred regularly since the 16 th century. I return to these claims below.

\section{So what is neoliberalism?}

Given the polyvalence of the core term, diverse typologies of neoliberalism exist. Here I present one concerned with the economic and political dimensions of neoliberalism and its changing fortunes. Neoliberalization is a distinctive economic, political, and social project that tends to judge all economic activities in terms of profitability and all social activities in terms of their contribution to differential capital accumulation. This might suggest that neoliberalism promotes the primacy of the economic but, because its extension and reproduction require continuing state support and, indeed, often involve what Weber (1975) called 'political capitalism', one might well argue that it 
entails a primacy of the political. I now offer a baseline definition and identify four forms of neoliberalism; relate neoliberalism to the world market, geopolitics and global governance; and address the role of the political in promoting neoliberalism and handling its contradictions and crisis-tendencies.

Four main historical forms of neoliberalism can be distinguished, although hybrid forms also exist. The most radical form was neoliberal system transformation in post-Soviet successor states. Russia and Poland provide two contrasting cases: Chicagoan 'creative destruction' induced by neoliberal shock therapy and a more Ordoliberal 'market therapy without shock' respectively. Such cases concern the Eurasian heartland, however, not the heartland of neoliberalism.

The latter is characterized by neoliberal regime shifts. Breaking with the post-war Atlantic Fordist settlements, based on an institutionalized compromise between capital and labour, neoliberal policies were pursued in order to modify the balance of forces in favour of capital. The neoliberal policy platform has six key planks: liberalization, deregulation, privatization, market proxies in the public sector, internationalization, and cuts in direct taxation. These policies have largely succeeded: witness stagnant real wages; cuts in welfare; increasing personal debt to invest in housing, pensions, education, and health or, indeed, to maintain a previous standard of living; and a growing share of income and wealth going to the top decile (especially the top percentile) of their respective populations. Well-known cases are Thatcherism and Reaganism but similar shifts occurred in Australia, Canada, New Zealand, Eire, Iceland, and Cyprus. While often identified with right-wing parties, neoliberal regime shifts have also been initiated, maintained or supported by centre-left parties, often under a 'Third Way' label (e.g., the Clinton Administration or New Labour). Moreover, as noted, with help from northern friends and/or military dictatorships, neoliberal regime shifts were actually pioneered in the outer crescent in Latin America.

The third type comprises economic restructuring and regime shifts that were mainly imposed from outside by transnational economic institutions and organizations backed by leading capitalist powers and partners among domestic political and economic elites. It involves neoliberal policies in line with the 'Washington Consensus' as a condition for financial and other aid to crisis-ridden economies outside the heartlands 
in parts of Africa, Asia, Eastern and Central Europe, and Latin America. While policies in types two and three often overlap in the (semi-)periphery of the global economy, they involve analytically distinct roots, lessons learnt, and likely forms of resistance.

Fourth, neoliberalism can involve a more pragmatic, partial, and potentially reversible set of neoliberal policy adjustments. Not all of the six neoliberal economic policies listed above have been adopted in such cases. They involve more modest and piecemeal changes deemed necessary by governing elites and their social base(s) to maintain existing economic and social models in the face of specific crisis-tendencies and the challenges created by globalization. Nordic social democracies and Rhenish capitalism provide examples. However, such adjustments can cumulate despite the fluctuating political fortunes of the parties that back them and, almost by stealth, can lead to neoliberal regimes (witness Germany in the last 25 years). Moreover, with the contagion of the North Atlantic Financial Crisis and the distinctive problems rooted in the Eurozone crisis, these changes have become harder to reverse. Indeed, as I note below, there are attempts to institutionalize neoliberalism in a succession of pacts and crisis-management responses in the Eurozone economies. This creates the paradox that an Ordoliberal Germany, which has made regular neoliberal policy adjustments to secure its neo-mercantilist export-led growth model, is backing the austerity demands of transnational financial capital that effectively impose a technocratic neoliberal regime shift on Greece and Spain.

It should be noted that none of these forms of neoliberalism (or neoliberalization) result from the spontaneous operation of market forces: they all involve the exercise of political power to establish and consolidate them and, when confronted with crisis, to rescue them. This illustrates the importance of Max Weber's three types of political capitalism: unusual deals with political authority, accumulation through force and domination, and predatory economic activities. Financialization and what Birch (2015) calls 'assetization' are crucial aspects of the development of neoliberal regime shifts; so are the lowering of taxes on rich households, big corporations, and too-big-to-fail financial institutions. This shows again that neoliberal regime shifts do not conform to the 'theoclassical' account of the free market. 
Neoliberalization in the heartlands has involved four main stages to date. First came the rollback of the institutions and institutionalized compromises associated with the Atlantic Fordist post-war settlement. Second, there were efforts to roll forward neoliberal institutions, consolidate the shift in the balance of forces, and constitutionalize neoliberal principles nationally, regionally, and globally - making them harder to reverse even if the political conjuncture temporarily favours socialist or populist right-wing parties and movements. The third stage was blowback as the unintended but inevitable effects of a one-sided emphasis on serving the interests of export-oriented and/or interest-bearing capital led to growing resistance, boom and bust cycles, and recessions. This is the moment of the 'Third Way' and analogous attempts to provide flanking and supporting mechanisms to maintain the momentum of neoliberal regime shifts. Fourth, after the eruption of the North Atlantic Financial Crisis, which is the product of finance-dominated accumulation (see below), central banks and states in the neoliberal heartlands intervened massively to rescue banks at the expense of households, public debt, and industrial capital. Efforts were made to transform the politics of austerity into a permanent state of austerity. Indeed, notwithstanding a brief period when the global financial crisis was construed as a crisis of rather than in neoliberalism, massive state intervention has since created conditions for a return to neoliberal 'business as usual' in the neoliberal heartlands. Elsewhere in Europe it has prompted Ordoliberal policy adjustments alongside efforts to maintain free trade, extend it to services, facilitate non-speculative capital flows, and find market solutions to climate change and other global challenges.

\section{The economic significance of neoliberalism}

To establish why neoliberalisms and neoliberalization have been and, despite their respective crisis-tendencies, remain so influential, leading to the renewal of neoliberalization rather than its retreat, we must look beyond its intellectual appeal and its domestic and international political backing. It is also related to the logic of capital and the distinction between the use-value and exchange-value aspects of the commodity. In the first instance, the commodity is both a use-value and an exchangevalue: without use-value, it would not be purchased; without exchange-value, it would not be produced. Analogous properties are found in other dimensions of the capital relation. The worker is both a concrete individual with specific skills, knowledge, and 
creativity and an abstract unit of labour power substitutable by other such units (or, indeed, other factors of production); the wage is both a source of demand and a cost of production; money functions both as a 'national' currency circulating within a monetary bloc and subject to state control and as an international money exchangeable against other monies in currency markets; productive capital is a more or less concrete stock of time- and place-specific assets undergoing valorization and abstract value in motion (notably as realized profits available for re-investment); land is a gift of nature and a monopolistic claim on revenues; knowledge circulates as part of the intellectual commons and can also become the object of intellectual property rights; and so forth. In each case, neoliberalism privileges exchange-value over usevalue. It emphasizes cost reduction and cost recovery and subjects all economic activities to the treadmill of matching or exceeding the prevailing world market average rate of profit.

Such one-sided treatment can only disguise, but not suppress, the significance of the use-value aspect of these relations. Eventually its importance to the reproduction of capitalism (and social life more generally) is reasserted and, in the absence of appropriate ways to handle the contradictions between use- and exchange-value, crises emerge that forcibly re-impose the unity of the capital relation. Accompanying this, however, as elaborated below, is the rise of a permanent politics of austerity and a tendential shift to an enduring state of austerity that is characterized by the 'constitutionalization of austerity' (Bruff 2014) as a political principle and an increasing attack on the institutions and practices of liberal democracy (see the penultimate section of this contribution).

The neoliberal policy paradigm not only privileges capital over labour but also privileges some fractions of capital over others. For it is capital in its exchange-value aspect that is most easily disembedded from broader socio-spatial-temporal contexts and thereby freed to 'flow' relatively smoothly through space-time. In this sense, compared to the largely intermediary role of finance in Fordist regimes and in a productivist, post-Fordist knowledge-based economy, neoliberalism promotes a finance-dominated accumulation regime. This tends to privilege hypermobile financial capital at the expense of capitals that are embedded in broader sets of social relations and/or that must be valorized in particular times and places; it creates the conditions 
for differential accumulation in favour of the financial sector based on financial innovation and speculation; and it increases inequalities of income and wealth, limiting the impact of the wage as a source of demand (cf. Dore 2008; Krippner 2005). Its destructive impact is reinforced through the neoliberal approach to accumulation through dispossession (especially the politically-licensed plundering of public assets and the intellectual commons) and the dynamic of uneven development (enabling financial capital to move on when the disastrous effects of financialization weaken those productive capitals that have to be valorized in particular times and places). It is also a powerful mechanism of world market integration, for good or ill, affecting different varieties of capitalism in different ways and transmitting crisis-tendencies through diverse mechanisms.

\section{Finance-dominated accumulation}

Against Kean Birch's argument that financial crises have occurred over four centuries and are too frequent to be attributable to neoliberalism (at least in its textbook form), I argue that neoliberalism has created a very special kind of financialization with distinctive forms of crisis and crisis-management. Much work on financialization focuses on the role of finance in the circuits of capital. Four relevant definitions are:

- the transformation of future streams of (profit, dividend, or interest) income into a tradable asset like a stock or a bond;

- a 'pattern of accumulation in which profit making occurs increasingly through financial channels rather than through trade and commodity production' (Krippner 2005: 174);

- $\quad$ an increasing tendency to the autonomization of the circuits of finance capital as property (or fictitious capital) from finance capital as functioning capital within the circuits of the 'real economy' (Meacci, 1998: 191-5); and

- $\quad$ the systemic power and importance of financial markets, financial motives, financial institutions, and financial elites in the operation of the economy and its governing institutions, nationally and internationally (Epstein 2005: 3).

The third and fourth definitions are especially relevant for my analysis. The neo-liberal 
form of world market integration greatly benefits interest-bearing capital because it controls the most liquid, abstract, and generalized economic resource and because it has also become the most integrated fraction of capital (cf. Demirović and Sablowski 2013). Interest-bearing capital (which differs from traditional usury capital) can facilitate the accumulation of profit-producing capital and it can also function as property, when it is simply one revenue-generating asset among others. In this latter context it underpins a finance-dominated accumulation regime. This is an extreme form of marketization of economic relations in which fictitious money, fictitious credit, fictitious capital, and, indeed, unsustainable fictitious profits play an increasing role in shaping economic performance and crisis-tendencies (Marx 1967[1894]; Jessop 2013; de Medeiros Carneiro et al., 2015;). Such regimes emerge to the extent that the Formatted: English (United Kingdom) circuits of interest-bearing capital become increasingly autonomous from those of profit-producing capital. Of course, financial capital as property cannot become fully and permanently detached from the need to valorize profit-producing capital. On the contrary, because continued expansion depends heavily on the pseudo-validation of highly leveraged speculative and Ponzi debt, this regime has its own inherent crisisgenerating mechanism. Elsner (2012) explains this as follows: Financial capital in a finance-dominated regime has a target rate of return that is several times greater than the historic norm for profit-producing capital and, worse still, in seeking to achieve it, massively levers fictitious credit and capital. In aggregate, the eventual validation of this capital would demand a total volume of surplus-value that far exceeds the productive and exploitative capacity of existing profit-producing capital.

This explains the emergence of financial crises that develop relatively independently, at least initially, from crisis-tendencies rooted in capitalist production. Indeed, the greater and longer the seeming independence of financial capital and the greater the resulting parasitism of finance as property, the greater and longer the crises required to re-impose the organic unity of the circuits of capital. Attempts to overcome the contradiction identified by Elsner depend on three equally unsustainable strategies. One is to create and manage bubbles, the main redistribution mechanism in financedominated accumulation, and then bail out (or get bailed out) at the right moment (Elsner 2012: 146-7; also Hudson 2012). This requires the complicity of central banks and government in finance-dominated economies. Another is to invoke a systemthreatening 'financial emergency' that justifies efforts to reduce individual and social 
wages, impose internal devaluation and financial repression, and privatize public services and assets to pay off the public debt incurred in massive bailouts (cf. Mirowski 2013). States have key roles here and this strategy has reinvigorated neo-liberalism and supported the politics of austerity (see below). The third approach, involves statesponsored primitive accumulation (e.g., land-grabbing, capitalizing nature and its services, and enclosing the intellectual commons). Albeit in different ways, all three strategies are implicated in the politics of austerity, whether as its cause and/or one of its mechanisms.

\section{Austerity}

We can understand the relation between neoliberalism and austerity if we consider the latter in terms of the relations between the economic and political fields, including their basic forms and institutional architecture, and their mediation through the changing balance of forces. The conventional distinction between policies, politics, and polity is useful here. It indicates that austerity can take three forms. First, there are conjunctural austerity policies that are introduced initially as temporary measures in response to short-term or immediate problems. As the conjuncture becomes favourable again, these policies are suspended or reversed. Second, there is the enduring politics of austerity (often called 'permanent austerity') that is promoted in response to a 'chronic' crisis, real or manufactured, in the fisco-financial domain and/or in the economy more generally. This is intended to bring about a more lasting reorganization of the balance of forces in favour of capital rather than to make policy adjustments to safeguard existing economic and political arrangements. Third, there is the austerity polity. This results from a continuing fundamental institutional reorganization of the relations between the economic and political in capitalist formations. It can be a possibly unintended cumulative result of the enduring politics of austerity, especially where this aggravates the underlying causes of fisco-financial crisis. It can also result from a deliberate strategy to subordinate the polity more directly and durably to the 'imperatives' of 'globalization' as these are construed in neoliberal discourse with its one-sided emphasis on the logic of exchange-value. And, given the political, ideological, hegemonic, and organic crises that have developed in the context of the financial, economic, and fisco-financial crises, they can also develop as an 
authoritarian response to growing popular unrest (including right-wing extremism) about the technocratic and plutocratic nature of crisis responses.

Conjunctural policies are found in the pattern of neoliberal policy adjustment (the fourth type of neoliberalism discussed above) and are associated with targeted cuts in specific areas. In contrast, an enduring politics of austerity is characteristic of neoliberal regime shifts and assumes the form of general fisco-financial restraint, putting downward pressure on most areas of expenditure, especially discretionary ones (Pierson 2001; Ferrera 2008; Seymour 2014). This pattern can occur in normal forms of politics, in states of economic emergency or in lasting states of exception. It can be triggered by a genuine crisis, one that is deliberately exaggerated, or one 'manufactured' for political purposes. Indeed, in neoliberal regimes, whatever the state of the economy, it seems that it is always the right time to reduce public expenditure (except for corporate welfare) through an appropriately crafted (and crafty) politics of austerity. This involves more than quantitative cuts in spending because it is also intended to have transformative effects that restructure, recalibrate, and reorient state expenditure. These measures are pursued to consolidate and extend the power of capital, especially interest-bearing capital, and to subsume ever wider areas of social life under the logic of differential accumulation.

Seymour (2014) argues that austerity is now the dominant political articulation of the global economic crisis in Europe and North America. In addition, with others, he notes that the politics of permanent austerity is not just a response to economic crisis but also to political and ideological crises and, indeed, an organic crisis of the capitalist social order (Seymour 2014: 4; Bruff 2014; Kannankulam and Georgi 2012; Jessop 2015; cf. Gramsci 1971). This is used to justify a state of economic emergency that is presented initially as a 'temporary' response to immediate or chronic problems but then acquires more permanent form through cumulative and mutually reinforcing institutional change, routinization of exceptional measures, and habituation.

Seymour identifies seven aspects of this strategy: (1) rebalance the economy from wage-led to finance-led growth; (2) redistribute income from wage-earners to capital; (3) promote 'precarity' in all areas of life as a disciplinary mechanism and means to reinforce the financialization of everyday life; (4) recompose social classes, with 
increasing inequality in income and wealth and greater stratification within classes; (5) facilitate the penetration of the state by corporations; (6) accelerate the turn from a Keynesian welfare state based on shared citizenship rights to a workfare regime that relies on coercion, casual sadism, and, especially in the US, penality; and (7) promote the values of hierarchy and competitiveness (Seymour 2014: 2-4). In many respects, these aspects were already inscribed in the politics of neoliberal regime shifts (as described above) but, for Seymour, they have been heavily reinforced following the 2007-9 financial and economic crisis (cf. Fumagalli and Lucarelli 2011). This occurs in part because the painful measures already taken to consolidate budgets in the 1990s and early 2000s were wiped out by the impact of the North American Financial Crisis and the Eurozone crisis as governments took on more debt to bail out banks and/or engineer stimulus packages (Rasmus 2010; Hudson 2012).

The politics of austerity can be interpreted as a long-term strategic offensive that continues and extends the neoliberal project to reorganize the institutional matrix and balance of forces in favour of capital. It aims to rearticulate relations between (1) the social power of money as capital and of capital as property and (2) the political power of the state. Inter alia, this involves a politics aimed at disorganizing subaltern classes and reorganizing the capitalist power bloc around interest-bearing capital (in neoliberal regimes) and export-oriented profit-producing capital (in economies where neoliberal policy adjustments prevailed). In the Eurozone, for example, the central goal of authoritarian crisis constitutionalism is to deepen EU integration on neoliberal terms and to govern through the treadmill dynamics of competitive austerity. Its aims include socializing bank losses; exploiting the sovereign debt crisis to restructure welfare states and labour markets (including further measures to weaken trade union bargaining power) and to impose shock therapy in the periphery (witness Cyprus and, currently, Greece). In finance-dominated regimes in the heartlands of neoliberalism and export-oriented regimes in the northern European Eurozone economies, the overall approach can switch between offensive and defensive tactics (the latter is exemplified by the 'Third Way', with its flanking and supporting mechanisms to maintain the overall momentum of neoliberal transformation). This is an important feature of variegated neoliberalization, which is flexible, adaptable, and resilient, tending as Peck (2010) writes, to 'fail forward', i.e., to exploit threats to its survival as opportunities for expansion. The successful pursuit of this strategy, which is not 
guaranteed, leads to an austerity state embedded in a political system (polity) that institutionalizes a 'permanent' politics of austerity.

Critics from the right as well as the left have noted this trend and described it in various ways. For example, Albo and Fanelli (2014) refer to a bipartisan or pluripartisan 'disciplinary democracy' as the political form of 'permanent austerity' (cf. Rasmus 2010; Stützle, 2013). Likewise, Bruff (2014) refers to authoritarian neoliberalism; Solty (2013) identifies an authoritarian crisis constitutionalism oriented to the economic governance of competitive austerity; and Oberndorfer (2015) describes the development of authoritarian competitive statism. From a social democratic perspective, Streeck (2014) highlights a move from the welfare state to the consolidation state; and a (former) Fabian Socialist, Crouch, describes the transition to post-democracy (2004). On the libertarian right, there is condemnation of the strong and repressive state that emerges from allegedly unconstitutional intervention to shore up finance capital and to police dissent (e.g. Stockman 2013). Critics also note that the scope for material concessions to subaltern groups has shrunk and, faced with growing resentment and sometimes open resistance, capitalist states are also becoming less open and democratic and increasingly coercive. It also creates different kinds of state and representational crisis that weaken the state even as its powers seem to expand (Poulantzas 1979; Bruff 2013).

\section{Debt-default-deflation dynamics in the US and UK}

The one-sided pursuit of neoliberalization in the United States and United Kingdom created the conditions for a debt-default-deflation dynamic that has worsened public finances as well as the private sector (Rasmus 2010). This possibility is inherent in finance-dominated accumulation and was actualized first in the USA and then in the UK. The features of the crisis in both are typical of finance-dominated accumulation but the financial sector is more significant in the UK and, in addition, the USA has the 'exorbitant privilege' of the dollar as world money and a labour force that has suffered stagnant real incomes for 30 years - longer than in the UK.

In the US, the crisis passed through several stages: credit crunch, liquidity crisis, financial insolvencies, a generalized financial crisis, a recession that risked becoming 
an epic recession or great depression, and then a manufactured 'public debt' crisis reflected in a surreal fiscal cliff debate in 2010-13. The initial response to the NAFC was the bailout of 'too big to fail' banks mainly as a covert strategy to recapitalize the banking system and socialize losses. This massively increased public debt and reinforced government dependence on bondholder confidence and 'Mr Market' more generally. Although there was also a federal stimulus package, it could not compensate for falling demand due to wage cuts plus austerity measures introduced at state and local level (where governments must balance their budgets). A scissors effect occurred as public expenditure and debt rose and GDP fell, so that debt increased as a proportion of GDP (the same tendency occurs elsewhere too). This fuelled the neoliberal hysteria around the long term costs of Medicaid, Medicare, and Social Security and the broader 'fiscal cliff' debate. Yet of the projected 7 trillion US\$ deficit, some 4 trillion was due to consolidation of tax cuts introduced by the George W. Bush Administration and 1 trillion to an increased defence budget (Solty 2013). The accompanying proposals for deficit reduction never seriously examined cuts in defence spending, ending unfunded wars, halting subsidies to a broad spectrum of corporate interests (often with large reserves, often held offshore), or restoring tax rates on the rich to Reagan era levels, despite stagnant wages and increased wealth inequalities to match those of the roaring 'twenties (Piketty 2014).

The UK also experienced a neoliberal regime shift, continued after the Thatcher years under successive Conservative, New Labour, the Conservative-Liberal Democratic coalition, and, now (June 2015), a Conservative majority regime. The United Kingdom is even more dominated by international financial capital than the United States thanks to the economic dominance of the City of London and the concentration of power in London, which has also entrenched a pattern of uneven development that favours London and the rest of the South East. Thus the NAFC had a greater and more lasting impact in the UK and this has been exacerbated by the more rigid politics of austerity pursued under Osborne's neoliberal Chancellorship, with its procyclical commitment to balanced budgets (a prospect moving into an ever more distant future as the debtdeflation spiral continues), its Ricardian approach to workfare, and its preferential tax treatment of corporations and the wealthy that is not reflected in renewed investment in profit-producing capital in the UK economy (see Seymour 2014). Without the exorbitant privilege of the dollar and the recent trend in the United States to energy 
independence, the UK has been lagging behind with its recovery based on new asset bubbles fuelled by quantitative easing and vulnerable to secular stagnation in the Eurozone.

These developments help to situate the continuing attempts led by the US and UK to pursue 'trade agreements' as a stimulus to crisis-ridden economies, such as the Transpacific Partnership (TPP), Transatlantic Trade and Investment Pact (TTIP), and Trade in Services Agreement (TiSA). If implemented, these treaties will limit state sovereignty to challenge transnational capital. One effect could be to enforce a neoliberal project of 'total privatization' of state-owned non-financial assets. Some 9 trillion US\$ of government land and buildings has been identified in OECD countries, equivalent to some $18 \%$ of their gross general government debt (The Economist, 2014). According to neoliberal budgetary and new public management principles, these should be monetized through public private-partnerships, contracting-out and leasing opportunities or even fully privatized.

\section{The Eurozone crisis and the constitutionalization of austerity}

European economic space is organized in the shadow of the German export-led growth regime that, despite significant and cumulative neo-liberal policy adjustments in the labour market, has remained firmly inside the 'co-ordinated market economy' camp (Bellofiore et al. 2010; Cesaratto and Stirati 2010; Streeck 2009). Its influence in this regard is reinforced by the extension of the German space economy to include elements of other Rhenish economies in Northern Europe. The prime strategic goal is to maintain Germany's export competitiveness and the regional and international stability on which its exports depend. The development of Economic and Monetary Union (EMU) was expected to enhance the competitiveness of French and German industrial capital, especially when reinforced by direct wage restraint, a reduced social wage, and lowered domestic consumption. Reflecting the banking tenets of das Modell Deutschland, EMU operated on two key principles: first, the European Central Bank (ECB) may not act as lender of last resort to insolvent banks or indebted states; and, second, sovereign debts may only be discharged by their respective member states (Varoufakis 2013). However, as the crisis-tendencies inherent in neoliberalism interacted with uneven development in Europe, the rigidities of EMU, and the faulty 
institutional design of economic governance in the European Union (absent a banking union, a fiscal union, and an EU welfare regime based on solidarity), it has produced an even more serious crisis than we find in its heartlands (Jessop 2014).

The contagion effects of the NAFC led to the virtual insolvency of many of Europe's big banks and required urgent measures to recapitalize them and nationalize toxic assets. As in the United States, this led to further concentration in banking. It also threatened a domino effect of sequential bankruptcy of vulnerable member states and their respective banking systems, starting with Greece and Eire and with the systemically important cases of Spain, Italy, and France looming on the near horizon. Without the right to exit the Eurozone and regain competitiveness through devaluation (among other measures), the intensification of the Eurozone crisis exposed the peripheral economies to domestic debt-default-deflation dynamics as well as to austerity measures mistakenly adopted by other member states and European institutions in the belief that they would limit or resolve the wider crisis. Crisismanagement responses premised on deep cuts in spending and regressive taxation actually proved procyclical, provoking a mutually reinforcing downward spiral of actual or feared private and sovereign debt-default-deflation dynamics in the periphery. This is now spreading to the core of the Eurozone as contagion effects reverberate.

\section{Conclusions}

Despite the continuing crises and bubble dynamics, the neoliberal project still dominates world society thanks to the path-dependent effects of policies, strategies, and structural shifts that were implemented during its highpoint and further measures introduced since to preserve its corrosive dynamic. This is linked to crisis-management in support of finance-dominated accumulation and accumulation via dispossession. These path-dependent effects are political and ideological as well as economic. They derive from the global weight of the US economy (including its pathological codependence with China) and the US state's role in shifting the contradictions of neoliberalism elsewhere and/or into the future. Thus neoliberal policies have shaped the forms, timing, and dynamics of economic crises (broadly understood) even in countries where they were not willingly embraced, coercively imposed, or unwittingly cumulated. For, in addition to the legacies of neoliberalism where it directly shaped 
politics and policies, it has also tended to disrupt the structured coherence of modes of regulation and/or governance where alternative policies prevailed. This can be seen in the wider geo-economic and geo-political effects of failed neoliberal system transformation and structural adjustment programmes and in the uneven terrain on which struggles over the economic, political, and social effects of neoliberalism are being contested.

The destabilizing consequences of budget-cutting in North America, Europe, and elsewhere are worrying even the high priests of neoliberalism in the International Monetary Fund, the World Bank, the World Economic Forum, and so on. In a joint report with the ILO, the IMF documented serious problems in labour markets reflected in rising unemployment worldwide. It warned that 'high and long-lasting unemployment... represents risks to the stability of existing democracies and hinders the development of new democracies in countries undergoing political transitions' (IMF/ILO 2010: 4). It added that premature fiscal retrenchment could harm growth and lead to even larger deficits and debts. Furthermore, abrupt shifts in fiscal policy stances, in many countries at the same time, could destabilize recovery and weaken future growth. It concluded that 'a credible and gradual return to fiscal stability over several years is likely to be a more successful strategy, not only for recovery and growth, but also for deficit and debt reduction... Social dialogue is essential to avoiding an explosion of social unrest' (IMF/ILO 2010). The IMF issued a similar warning in 2015, in the context of the crisis in Greece (IMF 2015). Likewise, in its 2014 Report on World Risks, the World Economic Forum identifies growing inequalities in wealth and income as the biggest single potential source of global instability. These are three of many similar examples of an impotent recognition of the limits to the politics of austerity.

\section{References}

Albo, G. and Fanelli, C. (2014) Austerity against democracy. An authoritarian phase of neoliberalism? Toronto: Socialist Project Canada. Available at www.socialistproject.ca/documents/AusterityAgainstDemocracy.pdf

Bellofiore, R., Garibaldo, F., and Halevi, J. (2010) The Great Recession and the Contradictions of European Neomercantilism. Socialist Register 2011: 120-46. 
Birch, K. (2015) We Have Never Been Neoliberal: A Manifesto for a Doomed Youth. Alresford: Zero Books.

Bruff, I. (2014) The Rise of Authoritarian Neoliberalism. Rethinking Marxism, 26 (1): 113-29.

Cesaratto, S., and Stirati, A. (2010) Germany and the European and Global Crises. Journal of International Political Economy, 39 (4): 56-86.

Crouch, C. (2004) Post-Democracy. Cambridge, UK: Polity.

de Medeiros Carneiro, R., Rossi, P., Santos Mello, G., and Chiliatto-Leite, V. (2015)

'The Fourth Dimension: Derivatives and Financial Dominance. Review of Radical Political Economics, 47: 641-62.

Demirović, A., and Sablowski, T. (2013) The Finance-dominated Regime of Accumulation and the Crisis in Europe. Berlin: Rosa Luxemburg Stiftung.

Dore, R. (2008) Financialization of the global economy. Industrial and Corporate Change, 17: 1097-1112.

Elsner, W. (2012) Financial Capitalism - At Odds with Democracy: The Trap of an 'Impossible' Profit Rate. Real-World Economics Review, 62: 132-159.

Epstein, G.A. (2005) Introduction. In Epstein, G.A., ed. Financialization and the World Economy. Cheltenham: Edward Elgar: 3-14.

Ferrera, M. (2008) The European Welfare State: Golden Achievements, Silver Prospects. West European Politics, 31: 82-107.

Fumagalli, A., and Lucarelli, S. (2011) Instability and Uncertainty in Cognitive Capitalism. In C. Gnos and L-P. Rochon, eds. Credit, Money and Macroeconomic Policy. Cheltenham: Elgar: 313-34.

Gramsci, A. (1971) Selections from the Prison Notebooks. London: Lawrence \& Wishart.

Hudson, M. (2012) The Bubble and Beyond: Fictitious Capital, Debt Deflation and the Global Crisis. Dresden: Islet.

IMF (2015) Greece. An Update of IMF Staff's Preliminary Public Debt Sustainability Analysis. IMF Country Report no. 15/186. Retrieved from: https://www.imf.org/external/pubs/cat/longres.aspx?sk=43080.0.

IMF/ILO (2010) The Challenges of Growth, Employment and Social Cohesion,

Retrieved from: http://www.osloconference2010.org/discussionpaper.pdf. Jessop, B. (2013) Credit Money, Fiat Money and Currency Pyramids. In J. Pixley and

G.C. Harcourt, eds, Financial Crises and the Nature of Capitalist Money. 
Basingstoke: Palgrave-Macmillan: 248-272.

Jessop, B. (2014) Variegated Capitalism, Modell Deutschland, and the Eurozone crisis. Journal of Contemporary European Studies, 22 (3): 248-60.

Jessop, B. (2015) The State: Past, Present, Future. Cambridge: Polity.

Kannankulam, J., and Georgi, F. (2012) Die Europäische Integration als Materielle

Verdichtung von Kräfteverhältnissen: Hegemonieprojekte im Kampf um das

'Staatsprojekt Europa'. Arbeitspapier Nr. 30. Marburg: Phillips-Universität.

Krippner, G.R. (2005) The Financialization of the American Economy. SocioEconomic Review, 3: 173-208.

Larner, W. (2003) Guest editorial. Environment and Planning D: Society and Space,

21: 509-12.

MacKinder, H.J. (1904) The Geographical Pivot of History. Geographical Journal, 23:

421-37.

MacKinder, H.J. (1919) Democratic Ideals and Reality: A Study in the Politics of Reconstruction. New York: Henry Holt \& Co.

Marx, K. (1967) Capital, Vol. 3. London: Lawrence \& Wishart <1894>

Meacci, F. (1998) Fictitious Capital and Crises. In Bellofiore, R., ed. Marxian Economics: Essays on volume III of Capital. Vol.1. Basingstoke, UK: Macmillan: 189-204.

Mirowski, P. (2013) Never Let a Serious Crisis go to Waste. London: Verso.

Mirowski, P., and Plehwe, D. eds. (2009) The Road from Mont Pèlerin, The Making of the Neoliberal Thought Collective. Cambridge: Harvard University Press.

Oberndorfer, L. (2015) From New Constitutionalism to Authoritarian Constitutionalism.

In J. Jäger and E. Springler, eds. Asymmetric Crisis in Europe and Possible

Futures. London: Routledge: 185-205.

Peck, J. (2010) Constructions of Neoliberal Reason. New York: Oxford University Press.

Peck, J., and Tickell, A. (2002) Neoliberalizing Space. Antipode,34: 380-404.

Pierson, P. (2001) Coping with Permanent Austerity. In P. Pierson, ed., The New Politics of the Welfare State. Oxford: Oxford University Press.

Piketty, T. (2014) Capital in the Twenty-first Century. Cambridge: Harvard University Press.

Poulantzas, N. (1979) The Political Crisis and the Crisis of the State. In J.W. Freiburg, ed., Critical Sociology. New York: Halsted Press: 373-393. 
Rasmus, J. (2010) Epic Recession: Prelude to Global Depression. London: Pluto.

Seymour, R. (2014) Against Austerity: How We Can Fix the Crisis They Made. London: Pluto.

Solty, I. (2013) Is the Global Crisis Ending the Marriage Between Capitalism and Liberal Democracy? In M. Lakitsch, ed., Political Power Reconsidered. Berlin: LIT: 161-204.

Stockman, D. (2013) The Great Deformation: The Corruption of Capitalism in America. New York: Public Affairs.

Streeck, W. (2009) Re-forming Capitalism. Institutional Change in the German Political Economy. Oxford: Oxford University Press.

Streeck, W. (2014) Buying Time: the Delayed Crisis of Democratic Capitalism. London: Verso.

Stützle, I. (2013) Austerität als Politisches Projekt. Münster: Westfälisches Dampfboot. The Economist (2014) Setting out the store, 11 January.

van der Pijl, K. (1998) Transnational Classes and International Relations. London and New York: Routledge.

Varoufakis, Y. (2013) From Contagion to Incoherence. Contributions to Political Economy, 2: 51-71.

Weber, M. (1975) Economy and Society. New York: Bedminster Press.

World Economic Forum (2014) Global Risks. Ninth edition. Cologny and Geneva: WEF. 